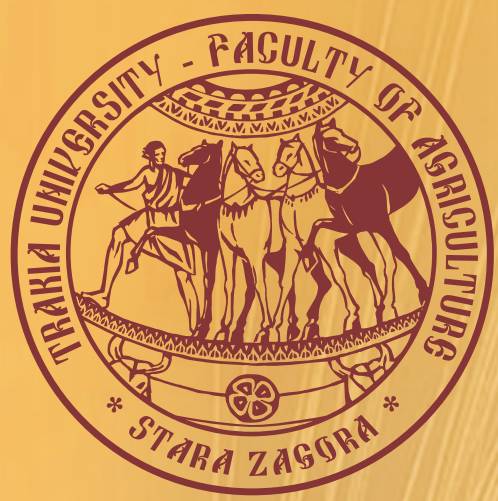

ISSN $1313-8820$ (print)

ISSN 1314 - 412X (online)

Volume 9 , Number 3

September 2017

\title{
AGRICULTURAL
}

\section{SCIENCE AND TECHNOLOGY}

\section{7}

An International Journal Published by Faculty of Agriculture, Trakia University, Stara Zagora, Bulgaria 


\section{Editor-in-Chief}

Georgi Petkov

Faculty of Agriculture

Trakia University, Stara Zagora

Bulgaria

E-mail: gpetkov@af.uni.sz.bg

\section{Co-Editor-in-Chief}

Dimitar Panayotov

Faculty of Agriculture

Trakia University, Stara Zagora

Bulgaria

\section{Editors and Sections}

\section{Genetics and Breeding}

Tsanko Yablanski (Bulgaria)

Atanas Atanasov (Bulgaria)

Svetlana Georgieva (Bulgaria)

Nikolay Tsenov (Bulgaria)

Max Rothschild (USA)

Ihsan Soysal (Turkey)

Horia Grosu (Romania)

Stoicho Metodiev (Bulgaria)

Bojin Bojinov (Bulgaria)

\section{Nutrition and Physiology}

Nikolai Todorov (Bulgaria)

Peter Surai (UK)

Ivan Varlyakov (Bulgaria)

George Zervas (Greece)

Vasil Pirgozliev (UK)

\section{Production Systems}

Radoslav Slavov (Bulgaria)

Dimitar Pavlov (Bulgaria)

Bogdan Szostak (Poland)

Banko Banev (Bulgaria)

Georgy Zhelyazkov (Bulgaria)

\section{Agriculture and Environment}

Martin Banov (Bulgaria)

Peter Cornish (Australia)

Vladislav Popov (Bulgaria)

Tarek Moussa (Egypt)

\section{Product Quality and Safety}

Stefan Denev (Bulgaria)

Vasil Atanasov (Bulgaria)

Roumiana Tsenkova (Japan)

\section{English Editor}

Yanka Ivanova (Bulgaria)
Scope and policy of the journal

Agricultural Science and Technology /AST/

- an International Scientific Journal of Agricultural and Technology Sciences is published in English in one volume of 4 issues per year, as a printed journal and in electronic form. The policy of the journal is to publish original papers, reviews and short communications covering the aspects of agriculture related with life sciences and modern technologies. It will offer opportunities to address the global needs relating to food and environment, health, exploit the technology to provide innovative products and sustainable development. Papers will be considered in aspects of both fundamental and applied science in the areas of Genetics and Breeding, Nutrition and Physiology, Production Systems, Agriculture and Environment and Product Quality and Safety. Other categories closely related to the above topics could be considered by the editors. The detailed information of the journal is available at the website. Proceedings of scientific meetings and conference reports will be considered for special issues.

\section{Submission of Manuscripts}

There are no submission / handling / publication charges.

All manuscripts written in English should be submitted as MS-Word file attachments via e-mail to editoffice@agriscitech.eu. Manuscripts must be prepared strictly in accordance with the detailed instructions for authors at the website

www.agriscitech.eu and the instructions on the last page of the journal. For each manuscript the signatures of all authors are needed confirming their consent to publish it and to nominate on author for correspondence.

They have to be presented by a submission letter signed by all authors. The form of the submission letter is available upon from request from the Technical Assistance or could be downloaded from the website of the journal. Manuscripts submitted to this journal are considered if they have submitted only to it, they have not been published already, nor are they under consideration for publication in press elsewhere. All manuscripts are subject to editorial review and the editors reserve the right to improve style and return the paper for rewriting to the authors, if necessary. The editorial board reserves rights to reject manuscripts based on priorities and space availability in the journal.

The journal is committed to respect high standards of ethics in the editing and reviewing process and malpractice statement. Commitments of authors related to authorship are also very important for a high standard of ethics and publishing. We follow closely the Committee on Publication Ethics (COPE), http://publicationethics.org/resources/guid elines

The articles appearing in this journal are indexed and abstracted in: DOI, EBSCO Publishing Inc., AGRIS (FAO) and DOAJ.

The journal is accepted to be indexed with the support of a project № BG051P00013.3.05-0001 "Science and business" financed by Operational Programme "Human Resources Development" of EU. The title has been suggested to be included in SCOPUS (Elsevier) and Electronic Journals Submission Form (Thomson Reuters).

The journal is freely available without charge to the user or his/her institution. Users can read, download, copy, distribute, print, search, or link to the full texts of the articles, or use them for any other lawful purpose, without asking prior permission from the publisher or the author.

This issue is printed with the financial support by Contract No DNP 0521/20.12.2016, financed from Fund 'Scientific Research' grant Bulgarian scientific Periodicals.

\section{Address of Editorial office:}

Agricultural Science and Technology Faculty of Agriculture, Trakia University

Student's campus, 6000 Stara Zagora

Bulgaria

Telephone: +35942699330 $+35942699446$

www.agriscitech.eu

Technical Assistance:

Nely Tsvetanova

Telephone: +359 42699446

E-mail:editoffice@agriscitech.eu 


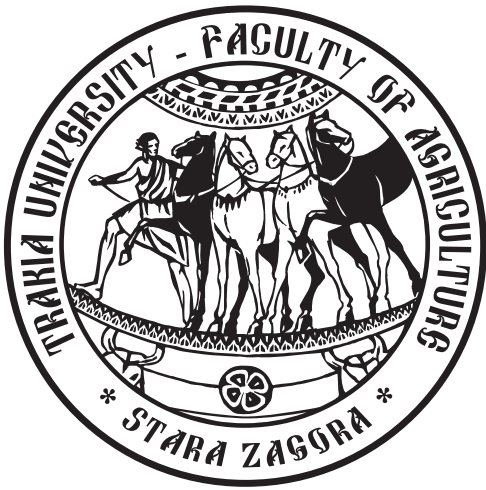

AGRICULTURAL

SCIENCE AND TECHNOLOGY

\section{7}

An International Journal Published by Faculty of Agriculture,

Trakia University, Stara Zagora, Bulgaria 


\title{
Nutrition and Physiology
}

\section{Variation in the chemical composition and physical characteristics of grain from winter barley varieties}

\author{
B. Dyulgerova*, N. Dyulgerov, D. Dimova \\ Institute of Agriculture, 8400 Karnobat, Bulgaria \\ (Manuscript received 4 July 2017; accepted for publication 28 August 2017)
}

\begin{abstract}
The aim of the study was to evaluate the range of variation in chemical composition and in physical parameters of grain associated with feed quality of barley under the conditions of Southeast Bulgaria. A set of 21 winter six-rowed barley varieties from different geographic origins were investigated. The study was conducted in the Institute of Agriculture - Karnobat, during the period 2013/2014 - 2014/2015. Grain samples of the studied varieties were analysed for crude protein, lysine, starch, crude fat, crude ash, crude fiber, hectoliter weight and 1000 grains weight. The coefficient of variation was the highest in crude fat (21.52\%) followed by lysine (9.52\%). Low variation among varieties was found in nitrogen-free extract (CV=1.56\%) and hectoliter weight (CV=2.77\%). Correlations of crude protein with lysine, starch and crude fiber were negative. Starch content was positively associated with crude fat and hectoliter weight. Significant negative correlation of nitrogen-free extract with crude fat and crude fiber was found. Differences in chemical composition and physical parameters of grain indicated that the studied varieties can provide a source of germplasm for breeding winter barley varieties with improved feed quality.
\end{abstract}

Keywords: barley, grain, chemical composition, physical parameters

\section{Introduction}

About $85 \%$ of the world's barley production is used for feeding animals. Animal feeders value barley, mainly as an energy source. They prefer barley with low fiber and high starch levels (high digestible energy levels). Barley protein is also economically significant due to high level of lysine, which is important for growing pigs and poultry. As the protein level in the animal's diet increases, the value of extra protein in barley also increases.

Many studies have been conducted to determine the quality requirements of barley grain used in livestock feeding (Newman and Newman 1992ab; Hunt 1996; Svihus and Gullord, 2002; Brand et al., 2003; Biel and Jacyno, 2013). Targeted breeding of barley varieties for a definite application purpose of the grain is connected with selection according to different criteria, because "grain quality" is a complex of quantitative characteristics depending on the physical parameters of grain and their chemical composition.

Barley varies greatly in chemical composition and physical characteristics due to genetic and environmental factors and their interaction (Metayer et al., 1993; Valaja et al., 1997; Scott et al., 1998; Andersson et al., 1999; Rodehutscord et al., 2016). Precipitations, temperature and fertilization are the most important environmental factors that contribute to variations in the chemical and physical characteristics of cereal grains (Metayer et al., 1993; Jorgensen et al., 1999; Dostálová et al., 2015; Rodehutscord et al., 2016). Therefore, the characterisation of variations in the nutritional value of barley grains in a given geographic location may help to define appropriate breeding objectives for improving the feeding value of barley grains for livestock nutrition.

The aim of this investigation was to study variation in chemical composition and physical characteristics of grain associated with feed quality of barley in 21 winter barley varieties in Southeast Bulgaria conditions.

\section{Material and methods}

This research was conducted during 2013/2014 and 2014/2015 growing seasons in the experimental field of the Institute of Agriculture - Karnobat, Southeastern Bulgaria. The experiments were organized in a Randomized Complete Block Design with 4 replications on plots of $10 \mathrm{~m}^{2}$.

The materials used in the present study included 21 varieties of six-rowed winter barley - Izgrev, IZ Bori, Bojin and Zemela from the Institute of Agriculture - Karnobat, Bulgaria; Atlas, Barberosse, Express, Maniton and Rebelle from France; Bronhild, Krimhild and Sigra from Germany; Finbul from Finland; Gerlah from Limagrain, Europe; Rombohedral from Hebei, China; Mihailo and Radical from Krasnodar Lukyanenko Research Institute of Agriculture, Russia; PA8649-95 from Pensylvania, USA; GA-Lutrell from Geogria, USA; Hampus from Sweden.

Grain samples from the studied varieties were ground in a laboratory mill with $1.0 \mathrm{~mm}$ sieve. Dry matter of grain samples was determined by drying the sample in an oven at $105^{\circ} \mathrm{C}$ until a constant weight was obtained and dry matter yield was calculated. Crude protein content (\%) was determined by the Kjeldahl method, and a conversion factor of 6.25 was used to convert total nitrogen to crude protein. Lysine content (as \% of crude protein) was determined by the Susoev method (Susoev, 1970). Starch content (\%) was determined by the Ewers polarimetric method. Crude fat (\%) was extracted with petroleum ether (boiling range of $40-60^{\circ} \mathrm{C}$ ) by the Soxhlet extraction method. Crude ash (\%) was determined by 
incineration in a muffle furnace at $550^{\circ} \mathrm{C}$ for $3 \mathrm{~h}$. Crude fiber (\%) was determined as the residue after sequential treatment with hot $\mathrm{H}_{2} \mathrm{SO}_{4}$ and hot $\mathrm{NaOH}$ according to the Weende method. Nitrogen-free extract (NFE) was calculated as follows: NFE $(\%)=100-($ moisture $\%+$ crude protein $\%+$ crude fat $\%+$ ash $\%+$ crude fiber $\%$ ).

Hectoliter weight $(\mathrm{kg} / \mathrm{hl})$ was determined by a volume meter and 1000 -grain weight $(\mathrm{g})$ was determined from the grain weight of 200 randomly taken grains multiplied by 5 .

The data of two years have been summarized and Pearson correlation coefficients were estimated using the computer software system of SPSS 16.00 for Windows (SPSS Inc., 2007). The cluster analysis was performed using the Complete-linkage method with software Statistica 7.0 (StatSoft Inc., 2004).

\section{Results and discussion}

The chemical composition and physical characteristics of grain of winter six-rowed barley varieties are presented in Table 1. The highest amount of crude protein was determined in variety Atlas $(13.12 \%)$, and the lowest amount of crude protein was found in variety Barberosse (10.75\%). The concentration of protein in barley is highly dependent on the cultivar and growth conditions (Oscarsson et al., 1996; Qi et al., 2006; Arendt and Zannini, 2013).
High crude protein content in barley grain is especially important for nutrient needs of ruminants (Newman and Newman, 1992a). The mean lysine content varied from $2.32 \%$ (Zemela) to $3.14 \%$ (IZ Bori). Lysine is the first limiting essential amino acid in barley and therefore an increased lysine content in protein results in improved nutritional quality (Eggum, 1977; Munck, 1992; Jorgensen et al., 1997; Jorgensen et al., 1999). Starch content ranged from $50.73 \%$ in variety Bronhild to $57.91 \%$ in variety Izgrev. The energy value of barley largely depends on its starch content (Newman and Newman, 1992b) and according to Griffey et al. (2010) selection for high starch concentration will facilitate the development of barley cultivars better suited for use in feed. The results showed that the lowest ash content was in variety Zemela $(2.50 \%)$ and the highest in variety Sigra $(2.89 \%)$. Crude fat values in barley varieties varied from $1.43 \%$ (Atlas) to $3.09 \%$ (Izgrev). Crude fiber ranged between $4.38 \%$ (Veslets) and $6.94 \%$ (Mihailo). The lowest concentration of nitrogenfree extract was found in Bronhild (63.74\%) and the highest in Veslets $(67.02 \%)$. Maximum hectoliter weight of $70.10 \mathrm{~kg} / \mathrm{hl}$ was exhibited by variety Veslets, whereas minimum hectoliter weight of $62.55 \mathrm{~kg} / \mathrm{hl}$ was recorded for the variety Sigra. Data for 1000 -grain weight ranged between $35.29 \mathrm{~g}$ and $48.90 \mathrm{~g}$, maximum 1000-grain weight was recorded for variety Finbul, whereas minimum was recorded for variety Bronhild. The obtained results for the chemical and physical characteristics of barley grain are comparable with

Table 1. Mean of chemical composition and physical characteristics of grain of winter six-rowed barley varieties (2013/2014 - 2014/2015)

\begin{tabular}{|c|c|c|c|c|c|c|c|c|c|}
\hline Varieties & $\begin{array}{c}\text { Crude protein, } \\
\%\end{array}$ & $\begin{array}{l}\text { Lysine, } \\
\%\end{array}$ & $\begin{array}{c}\text { Starch, } \\
\%\end{array}$ & $\begin{array}{c}\text { Ash, } \\
\%\end{array}$ & $\begin{array}{c}\text { Crude fat, } \\
\%\end{array}$ & $\begin{array}{c}\text { Crude } \\
\text { fiber, } \%\end{array}$ & $\begin{array}{c}\text { Nitrogen-free } \\
\text { extract }\end{array}$ & $\begin{array}{c}\text { Hectoliter } \\
\text { weight, kg/hl }\end{array}$ & $\begin{array}{c}1000 \text { grains } \\
\text { weight, } g\end{array}$ \\
\hline Veslets & 12.06 & 2.82 & 53.73 & 2.67 & 1.74 & 4.38 & 67.02 & 70.10 & 48.81 \\
\hline Izgrev & 11.09 & 3.07 & 57.91 & 2.67 & 3.09 & 6.27 & 64.89 & 69.15 & 43.41 \\
\hline IZ Bori & 11.22 & 3.14 & 52.34 & 2.60 & 1.45 & 5.64 & 66.86 & 67.65 & 40.68 \\
\hline Bojin & 11.35 & 2.98 & 52.82 & 2.61 & 1.71 & 6.33 & 65.63 & 68.45 & 46.53 \\
\hline Zemela & 13.00 & 2.32 & 52.21 & 2.50 & 1.88 & 4.55 & 65.60 & 69.15 & 40.63 \\
\hline Atlas & 13.12 & 2.35 & 53.98 & 2.68 & 1.43 & 5.54 & 64.77 & 69.90 & 45.29 \\
\hline Barberosse & 10.75 & 3.11 & 54.01 & 2.73 & 1.47 & 5.96 & 66.78 & 69.25 & 35.69 \\
\hline Bronhild & 12.84 & 2.74 & 50.73 & 2.80 & 2.15 & 6.18 & 63.74 & 64.10 & 35.29 \\
\hline Express & 11.87 & 2.41 & 53.35 & 2.78 & 2.53 & 6.27 & 64.27 & 69.30 & 47.88 \\
\hline Finbul & 12.38 & 3.01 & 52.88 & 2.65 & 2.00 & 6.25 & 64.14 & 68.20 & 48.90 \\
\hline Gerlach & 11.76 & 2.86 & 54.73 & 2.64 & 1.87 & 5.75 & 66.12 & 67.70 & 48.64 \\
\hline Hampus & 11.09 & 2.55 & 57.73 & 2.59 & 2.59 & 6.80 & 64.61 & 69.80 & 45.54 \\
\hline Maniton & 11.68 & 2.78 & 52.97 & 2.61 & 2.31 & 5.37 & 66.05 & 68.45 & 48.80 \\
\hline Rebelle & 11.47 & 2.89 & 52.14 & 2.74 & 2.34 & 6.75 & 64.36 & 67.75 & 40.10 \\
\hline Krimhild & 12.96 & 2.44 & 52.22 & 2.50 & 2.64 & 5.69 & 63.80 & 68.80 & 45.33 \\
\hline Sigra & 11.59 & 2.75 & 51.97 & 2.89 & 1.52 & 5.62 & 66.22 & 62.55 & 37.19 \\
\hline Rombohedral & 12.65 & 2.69 & 53.34 & 2.81 & 2.02 & 5.16 & 64.65 & 70.00 & 38.41 \\
\hline Mihailo & 11.12 & 3.03 & 56.71 & 2.61 & 2.26 & 6.94 & 64.61 & 67.20 & 37.80 \\
\hline PA8649-95 & 11.66 & 3.06 & 55.19 & 2.59 & 2.18 & 5.79 & 65.18 & 69.20 & 35.99 \\
\hline Radical & 12.08 & 2.64 & 54.90 & 2.59 & 1.77 & 5.43 & 65.87 & 67.15 & 41.62 \\
\hline GA-Lutrell & 12.00 & 2.49 & 55.77 & 2.64 & 2.16 & 6.32 & 64.31 & 69.55 & 44.44 \\
\hline$\overline{M e a n}$ & 11.89 & 2.77 & 53.89 & 2.66 & 2.05 & 5.86 & 65.21 & 68.26 & 42.71 \\
\hline Minimum & 10.75 & 2.32 & 50.73 & 2.50 & 1.43 & 4.38 & 63.74 & 62.55 & 35.29 \\
\hline Maximum & 13.12 & 3.14 & 57.91 & 2.89 & 3.09 & 6.94 & 67.02 & 70.10 & 48.90 \\
\hline CV\% & 5.94 & 9.52 & 3.57 & 3.75 & 21.52 & 11.42 & 1.56 & 2.77 & 11.14 \\
\hline
\end{tabular}


Table 2. Pearson correlation coefficients between the chemical and physical characteristics of grain of winter six-rowed barley varieties (2013/2014 - 2014/2015)

\begin{tabular}{|c|c|c|c|c|c|c|c|c|}
\hline & Lysine & Starch & Clude ash & Clude fat & Clude fiber & $\begin{array}{c}\text { Nitrogen-free } \\
\text { extract }\end{array}$ & $\begin{array}{c}\text { Hecto } \\
\text { liter weight }\end{array}$ & $\begin{array}{c}1000 \text { grains } \\
\text { weight }\end{array}$ \\
\hline Clude protein & $-0.676^{* *}$ & $-0.476^{*}$ & -0.069 & -0.093 & $-0.493^{*}$ & -0.400 & 0.035 & 0.116 \\
\hline Lysine & 1 & 0.128 & 0.093 & -0.097 & 0.269 & 0.367 & -0.172 & -0.257 \\
\hline Starch & & 1 & -0.263 & $0.415^{*}$ & 0.357 & -0.044 & $0.416^{*}$ & 0.115 \\
\hline Clude ash & & & 1 & -0.159 & 0.113 & -0.041 & $-0.448^{*}$ & -0.315 \\
\hline Clude fat & & & & 1 & $0.427^{*}$ & $-0.616^{\star *}$ & 0.209 & 0.178 \\
\hline Clude fiber & & & & & 1 & $-0.531^{*}$ & -0.149 & -0.096 \\
\hline Nitrogen-free extract & & & & & & 1 & -0.029 & 0.006 \\
\hline Hectoliter weight & & & & & & & 1 & $0.425^{*}$ \\
\hline
\end{tabular}

*,** significant at 0.05 and 0.01 level, respectively

those reported by Griffey et al. (2010), Makeri et al. (2013), Biel and Jacyno (2013), Alijošius etal. (2016).

Varieties Zemela, Atlas, Bronhild, Krimhild and Rombohedral were found to possess above $12.5 \%$ protein in grain. Izgrev, IZ Bori, Barberosse, PA8649-95 and Mihailo had high percentage of lysine in grain protein. A favorable combination of high protein, lysine, hectoliter weight and 1000-grain weight was found in variety Finbul.

The highest coefficient of variation (CV) was shown by crude fat $(C V=21.52 \%)$, followed by crude fiber ( $C V=11.42 \%)$. The lowest values of $\mathrm{CV}$ were shown by nitrogen-free extract and hectoliter weight $(\mathrm{CV}=1.56 \%$ and $\mathrm{CV}=2.77 \%$ ).
The correlation coefficients among the studied characteristics were presented in Table 2. Crude protein had a significant negative correlation with lysine, starch and crude fiber. Similar results have been reported by a number of other researchers in diverse environments (Briggs, 1978; Griffey et al., 2010; Pasam et al., 2012). Starch content in grain was positively associated with crude fat and hectoliter weight. Crude fat content had a positive correlation with starch and crude fiber and negative correlation with nitrogen-free extract. Significant negative correlations between crude fiber and nitrogen-free extract was found. Hectoliter weight had a positive correlation with starch content and 1000-grain weight and negative

Complete Linkage

Euclidean distances

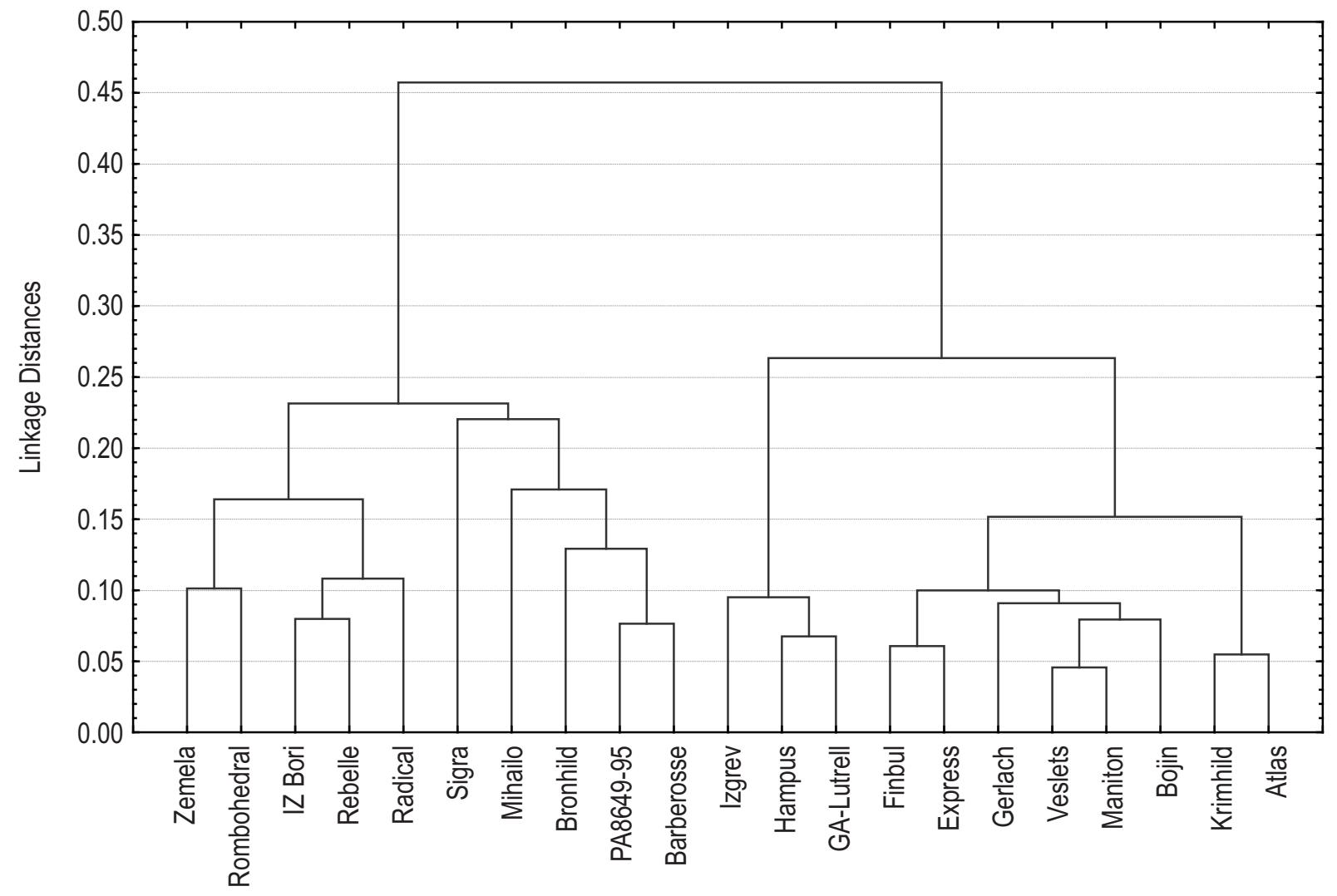

Figure 1. Cluster diagram of 21 winter six-rowed barley varieties on the basis of chemical and physical characteristics of grain (2013/2014 - 2014/2015) 
correlation with crude ash content. Kaur et al. (2016) also reported positive association between starch content and hectoliter weight. Significant positive correlation between starch and test weight was found by Cambell et al. (1995) and Griffey et al. (2010).

The dendrogram of the evaluated barley varieties is presented in Figure 1. The varieties were grouped into two clusters at a linkage distance of about 0.27 units. The first cluster is composed of 10 genotypes. The group is mainly characterized by low values for hectoliter weight and 1000-grain weight. The second cluster included 11 varieties with high hectoliter weight and 1000-grain weight. The groupings indicated no correspondence between geographical origin and clustering pattern. Two of the Bulgarian varieties Zemela and IZ Bori are situated in the first cluster and the other three Veslets, Izgrev and Bojin - in the second cluster. This might be explained by the fact that the qualitative traits are complex variables and depend on the interaction of a significant number of gene expressions not being related to the geographic origin.

\section{Conclusion}

The present study showed considerable differences in chemical and physical characteristics of barley grain in winter barley varieties grown in Southeast Bulgaria conditions. The highest coefficient of variation (CV) was shown by crude fat $(C V=21.52 \%)$, followed by crude fiber ( $C V=11.42 \%$ ). The lowest values of $C V$ were shown by nitrogen-free extract and hectoliter weight ( $C V=1.56 \%$ and $\mathrm{CV}=2.77 \%$ ). Correlations of crude protein with lysine, starch and crude fiber were negative. Starch content was positively associated with crude fat and hectoliter weight. Significant negative correlation of nitrogen-free extract with crude fat and crude fiber was found. Differences in chemical composition and physical parameters of grain indicated that the studied varieties could be potentially utilized in breeding of winter barley varieties with improved feed quality.

\section{References}

Alijošius S, Švirmickas GJ, Kliševičiūtè V, Gružauskas R, Šašytẻ V, Racevičiūtė-Stupelienè $A$, Daukšienẻ $A$ and Dailidavičienè J, 2016. The chemical composition of different barley varieties grown in Lithuania. Veterinarija Ir Zootechnika, 73, 9-13.

Andersson AAM, Elfverson C, Andersson R, Regne S and Aman P, 1999. Chemical and physical characteristics of different barley samples. Journal of Science of Food and Agriculture, 79, 979-986.

Arendt EK and Zannini E, 2013. Cereal Grains for the Food and Beverage Industries. Woodhead Publishing, Cambridge, p. 485.

Biel W and Jacyno E, 2013. Chemical composition and nutritive value of spring hulled barley varieties. Bulgarian Journal of Agricultural Science, 19, 721-727.

Brand TS, Cruywagen CW, Brandt DA, Viljoen M and Burger WW, 2003. Variation in the chemical composition, physical characteristics and energy values of cereal grains produced in the Western Cape area of South Africa. South African Journal of Animal Science, 33, 111-126.

Briggs DE, 1978. Barley. Chapman and Hall, New York, USA, p. 128.

Campbell LD, Biola RJ and Stothers SC, 1995. Variation in chemical composition and test weight of barley and wheat grain grown at selected locations throughout Manitoba. Canadian Journal of Animal Science, 75, 239-246.

Dostálová Y, Hřivna L, Kotková B, Burešová I, Janečková M and Šottníková V, 2015. Effect of nitrogen and sulphur fertilization on the quality of barley protein Plant Soil Environment, 61, 399-404.

Eggum BO, 1977. Nutritional aspects of cereal proteins. In: Genetic Diversity in Plants, eds Muhammed A, Aksel R \& von Borstel R C. Plenum Press, New York, USA, pp. 349-369.

Griffey C, Brooks W, Kurantz M, Thomason W, Taylor F, Obert D, Moreau R, Flores R, Sohn M and Hicks K, 2010. Grain composition of Virginia winter barley and implications for use in feed, food, and biofuels production. Journal of Cereal Science, 51, 41-49.

Hunt CW, 1996. Factors affecting the feeding quality of barley for ruminants. Animal Feed Science and Technology, 62, 37-48.

Jorgensen H, Gabert VM and Eggum O, 1997. The Nutritional Value of High-Lysine Barley Determined in Rats, Young Pigs and Growing Pigs. Journal of the Science of Food and Agriculture, 73, 287-295.

Jorgensen H, Gabert VM and Fernandez JA, 1999. Influence of nitrogen fertilization on the nutritional value of high-lysine barley determined in growing pigs. Animal Feed Science and Technology 79, 79-91.

Kaur S, Kaur H, Singh P, Cheema BS and Kumar V, 2016. Genetic variation and evaluation of exotic barley (Hordeum vulgare L.) genotypes for grain protein content, starch content and agronomic traits. Electronic Journal of Plant Breeding, 7, 1114-1121.

Makeri MU, Nkama I and Badau MH, 2013. Physicochemical, malting and biochemical properties of some improved Nigerian barley cultivars and their malts. International Food Research Journal, 20, 1563-1568.

Metayer JP, Grosjean F and Castaing J, 1993. Study of variability in French cereals. Animal Feed Science and Technology, 43, 87108.

Munck L, 1992. The case of high-lysine barley breeding. In: Barley: Genetics, Biochemistry, Molecular Biology and Biotechnology, Shewry, P.R. (ed.), CAB International, pp. 573-601.

Newman CW and Newman RK, 1992a. Characteristics of the ideal barley for feed, Barley research reviews 1986-91. In: Barley Genetics, VI Session and Workshops Summaries, Munksgaard International Publishers, 925-939.

Newman CW and Newman RK, 1992b. Nutritional aspects of barley seed structure and composition. In: Barley: Genetics, Biochemistry, Molecular Biology and Biotechnology, Shewry, P.R. (ed.), CAB International, pp. 351-368.

Oscarsson M, Anderson R, Salomonsson AC and Aman P, 1996. Chemical composition of barley samples focusing on dietary fiber components. Journal of Cereal Science, 24, 161-170.

Pasam RK, Sharma R, Malosetti M, Van Eeuwijk FA, Haseneyer G, Kilian B and Graner A, 2012. Genome-wide association studies for agronomical traits in a world wide spring barley collection. BMC PlantBiology, 12, 16 http://www.biomedcentral.com/1471-2229/12/. Qi JC, Zhang GP and Zhou MX, 2006. Protein and hordein content in barley seeds as affected by nitrogen level and their relationship to beta-amylase activity. Journal of Cereal Science. 43, 102-107.

Rodehutscord M, Rückert C, Maurer HP, Schenkel H, Schipprack W, Knudsen KEB, Schollenberger M, Laux M, Eklund M, Siegert W and Mosenthin R, 2016. Variation in chemical composition and physical characteristics of cereal grains from different genotypes. Archives of Animal Nutrition, 70, 87-107.

Scott TA, Silversides FG, Classen HL, Swift ML and Bedford MR, 1998. Effect of cultivar and environment on the feeding value of Western Canadian wheat and barley samples with and without 
enzyme supplementation. Canadian Journal of Animal Science, 78, 649-656.

SPSS Inc., 2007. SPSS for Windows. Release 16.0.SPSS Inc. Chicago, IL. USA.

StatSoft Inc., 2004. Statistica for windows. Tulsa (OK): StatSoft Inc. Susoev AF, 1970. A new method for determining the lysine. Scientific and Technical byulletin Vseseyuznego selection -technical Institute, vip.13, Odessa (Ru).
Svihus B and Gullord M, 2002. Effect of chemical content and physical characteristics on nutritional value of wheat, barley and oat for poultry. Animal Feed Science and Technology, 102, 71-92.

Valaja J, Suomi K, Alaviuhkola T and Mela T, 1997. Effects of variety, soil, type and nitrogen fertilizer supply on the nutritive value of barley for growing pigs. Agricultural and Food Science in Finland, 6, 295-303. 
Reviews

Problems and achievements of cotton (Gossypium Hirsutum L.) weeds control

T. Barakova, G. Delchev

Achievements and problems in the weed control in grain sorghum (Sorghum Bicolor Moench.)

G. Delchev, M. Georgiev

\section{Genetics and Breeding}

Parthenogenetic responsiveness of sunflower hybrid combinations with expressed tolerance to herbicides

M. Drumeva, P. Yankov

In vitro propagation of oil-bearing rose (Rosa damascena Mill.)

V. Badzhelova

\section{Nutrition and Physiology}

Variation in the chemical composition and physical characteristics of grain from winter barley varieties

B. Dyulgerova, N. Dyulgerov, D. Dimova

Haematological and serum biochemical indices of broiler chickens fed raw sickle pod (Senna obtusifolia) seed meal

C. Augustine, I.D. Kwari, J.U. Igwebuike, S.B. Adamu

Prey size selectivity of pikeperch (Sander Lucioperca L.) fed with topmouth gudgeon (Pseudorasbora Parva Temminck \& Schlegel)

M. Gevezova-Kazakova, M. Yankova, T. Hubenova, A. Zaikov, G. Rusenov

Influence of organic nitrogen amendment, containing amino acids on the cellulase and xylanase, produced by Trichoderma spp. isolates

D. Draganova, I. Valcheva, Y. Kuzmanova, M. Naydenov

\section{Production Systems}

Justification of a method for determining the moment for switching on the level one signaling of filled grain harvester hoppers

G. Tihanov, B. Kolev, K. Trendafilov, N. Delchev, Y. Stoyanov

Mathematical approaches for assessment and classification of the European Union member states based on the average yield of vegetables for the period 1961-2014

N. Keranova 
Present status of Zymoseptoria tritici (Mycospharella graminicola /Fuckel/ Schroter) of the wheat cultures in the Republic of Macedonia

I. Karov, E. Arsov

\section{Agriculture and Environment}

Influence of basic agrotechnical activities on the productivity and yield of Triticum monococcum $\mathrm{L}$.

S. Stamatov, K. Uzundzhalieva, E. Valchinova, G. Desheva, P. Chavdarov, B. Kyosev, T. Cholakov, R.

Ruseva, N. Velcheva

Avifauna abundance and diversity in Jos wildlife park, Nigeria

B.T. Kwaga, D. lliya, A. Ali, D. Khobe

Ecological analysis of the flora in the 'Chinarite' protected area - Rodopi municipality, Bulgaria

L. Dospatliev, M. Lacheva

Product Quality and Safety

Food emulsions with amidated pectin from celery (Apium graveolens var. rapaceum D. C.) tubers Iv. Petrova, N. Petkova, M. Ognyanov, Ap. Simitchiev, M. Todorova, P. Denev

M. Tonchev, T. Atanasov, A. Todorova, Ts. Atanasova, N. Shtrankova, M. Momchilova G. Zsivanovits

\section{Short Communication}

Influence of elevated platform (wire-mesh or wooden) in the cage on domestic rabbit (Oryctolagus cuniculus) activity

S. Peeva, E. Raichev, D. Georgiev, A. Stefanov 


\section{Instruction for authors}

\section{Preparation of papers}

Papers shall be submitted at the editorial office typed on standard typing pages (A4, 30 lines per page, 62 characters per line). The editors recommend up to 15 pages for full research paper ( including abstract references, tables, figures and other appendices)

The manuscript should be structured as follows: Title, Names of authors and affiliation address, Abstract, List of keywords, Introduction, Material and methods, Results, Discussion, Conclusion, Acknowledgements (if any), References, Tables, Figures.

The title needs to be as concise and informative about the nature of research. It should be written with small letter /bold, 14/ without any abbreviations.

Names and affiliation of authors The names of the authors should be presented from the initials of first names followed by the family names. The complete address and name of the institution should be stated next. The affiliation of authors are designated by different signs. For the author who is going to be corresponding by the editorial board and readers, an E-mail address and telephone number should be presented as footnote on the first page. Corresponding author is indicated with *

Abstract should be not more than 350 words. It should be clearly stated what new findings have been made in the course of research. Abbreviations and references to authors are inadmissible in the summary. It should be understandable without having read the paper and should be in one paragraph.

Keywords: Up to maximum of 5 keywords should be selected not repeating the title but giving the essence of study.

The introduction must answer the following questions: What is known and what is new on the studied issue? What necessitated the research problem, described in the paper? What is your hypothesis and goal?

Material and methods: The objects of research, organization of experiments, chemical analyses, statistical and other methods and conditions applied for the experiments should be described in detail. A criterion of sufficient information is to be possible for others to repeat the experiment in order to verify results.

Results are presented in understandable tables and figures, accompanied by the statistical parameters needed for the evaluation. Data from tables and figures should not be repeated in the text. Tables should be as simple and as few as possible. Each table should have its own explanatory title and to be typed on a separate page. They should be outside the main body of the text and an indication should be given where it should be inserted.

Figures should be sharp with good contrast and rendition. Graphic materials should be preferred. Photographs to be appropriate for printing. Illustrations are supplied in colour as an exception after special agreement with the editorial board and possible payment of extra costs. The figures are to be each in a single file and their location should be given within the text.

Discussion: The objective of this section is to indicate the scientific significance of the study. By comparing the results and conclusions of other scientists the contribution of the study for expanding or modifying existing knowledge is pointed out clearly and convincingly to the reader. Conclusion: The most important consequences for the science and practice resulting from the conducted research should be summarized in a few sentences. The conclusions shouldn't be numbered and no new paragraphs be used. Contributions are the core of conclusions. References:

In the text, references should be cited as follows: single author: Sandberg (2002); two authors: Andersson and Georges (2004); more than two authors: Andersson et al.(2003). When several references are cited simultaneously, they should be ranked by chronological order e.g.: (Sandberg, 2002; Andersson et al., 2003; Andersson and Georges, 2004).

References are arranged alphabetically by the name of the first author. If an author is cited more than once, first his individual publications are given ranked by year, then come publications with one co-author, two co-authors, etc. The names of authors, article and journal titles in the Cyrillic or alphabet different from Latin, should be transliterated into Latin and article titles should be translated into English. The original language of articles and books translated into English is indicated in parenthesis after the bibliographic reference $($ Bulgarian $=\mathrm{Bg}$, Russian $=\mathrm{Ru}$, Serbian $=\mathrm{Sr}$, if in the Cyrillic, Mongolian =
Mo, Greek = Gr, Georgian = Geor., Japanese $=\mathrm{Ja}$, Chinese $=\mathrm{Ch}$, Arabic $=\mathrm{Ar}$, etc.)

The following order in the reference list is recommended:

Journal articles: Author(s) surname and initials, year. Title. Full title of the journal, volume, pages. Example:

Simm G, Lewis RM, Grundy B and Dingwall WS, 2002. Responses to selection for lean growth in sheep. Animal Science, 74, 39-50

Books: Author(s) surname and initials, year. Title. Edition, name of publisher, place of publication. Example:

Oldenbroek JK, 1999. Genebanks and the conservation of farm animal genetic resources, Second edition. DLO Institute for Animal Science and Health, Netherlands.

Book chapter or conference proceedings: Author(s) surname and initials, year. Title. In: Title of the book or of the proceedings followed by the editor(s), volume, pages. Name of publisher, place of publication. Example:

Mauff G, Pulverer G, Operkuch W, Hummel K and Hidden C, 1995. C3variants and diverse phenotypes of unconverted and converted C3. In: Provides of the Biological Fluids (ed. $\mathrm{H}$. Peters), vol. 22, 143-165, Pergamon Press. Oxford, UK.

Todorov N and Mitev J, 1995. Effect of level of feeding during dry period, and body condition score on reproductive performance in dairy cows, IX $X^{\text {th }}$ International Conference on Production Diseases in Farm Animals, September 11-14, Berlin, Germany.

Thesis:

Hristova D, 2013. Investigation on genetic diversity in local sheep breeds using DNA markers. Thesis for PhD, Trakia University, Stara Zagora, Bulgaria, (Bg).

The Editorial Board of the Journal is not responsible for incorrect quotes of reference sources and the relevant violations of copyrights.

\section{Animal welfare}

Studies performed on experimental animals should be carried out according to internationally recognized guidelines for animal welfare. That should be clearly described in the respective section "Material and methods". 


\section{AGRICULTURAL \\ SCIENCE AND TECHNOLOGY}

Volume 9, Number 3

September 2017
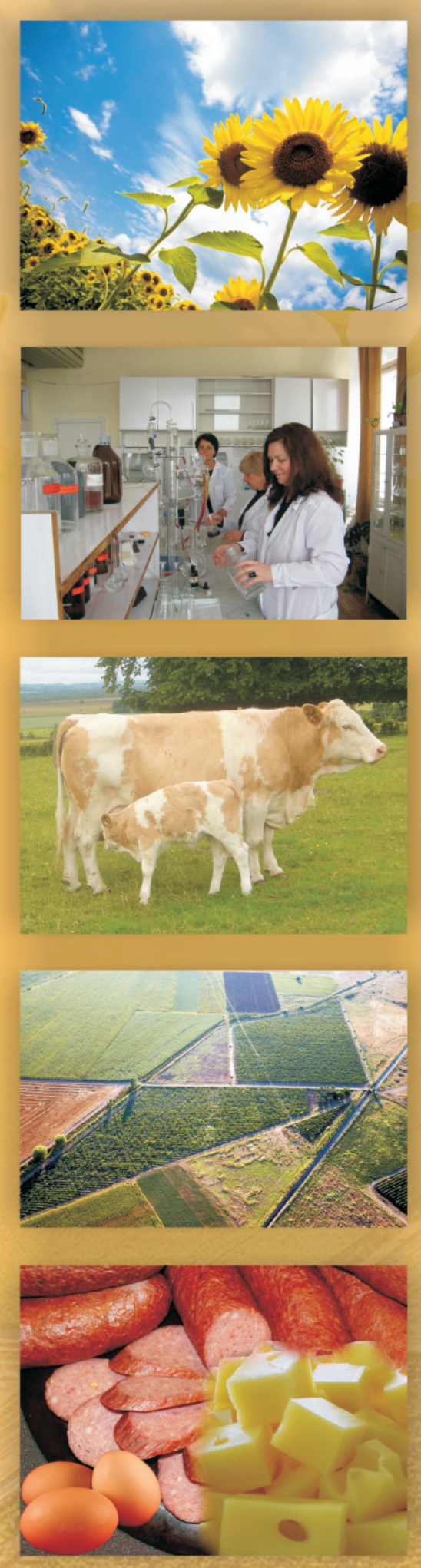

Journal web site: 